\title{
Antidiabetikum-hatékonyság és -biztonság időskorban
}

\author{
Domboróczki Zsolt dr. ${ }^{(1,2,3)}$
}

\begin{abstract}
Összefoglalás
Az idöskorú cukorbetegek kezelésével kapcsolatban korlátozott számú bizonyiték áll rendelkezésünkre. Bár ezek menynyisége nincs arányban e változatos fizikai, szellemi és szociális jellemzőkkel bíró populáció növekvö jelentöségével, a tendencia jó irányba mutat. Az elmúlt években mind az antidiabetikumok hatékonysága, mind biztonsága tekintetében új eredmények láttak napvilágot. Az orális és injektábilis készitmények vércukorcsökkentö hatékonysága, hypoglykaemiapotenciálja mellett kemény végpontú, kardiovaszkuláris kimeneti adatok ismertek. A korszerü, egyénre szabott antidiabetikus terápia nem nélkülözheti a gyarapodó evidenciák beépitését a mindennapi gyakorlatba. A szerzö célja a témához kapcsolódó irodalmi adatok áttekintése, összegzése.
\end{abstract}

Kulcsszavak: időskor, antidiabetikum, hypoglykaemia, individuális kezelés

\section{Efficacy and safety of antidiabetic treatment in elderly patients}

Summary: We have limited evidence concerning the treatment of elderly diabetic patients. Although the volume is not proportional to the increasing importance of this physically, intellectually and socially heterogeneous population - the trend is in the right direction. New results have emerged in the last few years both in terms of efficiency and safety of antidiabetics. Besides glucose lowering effect and hypoglycemia potential of these drugs, pleiotropic effects and cardiovascular outcome results are available. Modern, individualized treatment needs to incorporate these evidence into everyday practice. The author sums up literary data related to this topic.

Keywords: elderly people, antidiabetic drug, hypoglycemia, individualized treatment

\section{Rövidítések:}

ВОт: bázisinzulinnal kiegészített orális antidiabetikum terápia (basal insulin supported oral treatment); DPP4: dipeptidilpeptidáz-4; GLP-1: glukagonszerü peptid-1 (glukagon like peptid 1); NPH: neutrális protamin Hagedorn inzulin; SGLT2: nátrium-glukóz kotranszporter-2

A diabetes mellitus emelkedő prevalenciájának egyik oka az időskorúak számának és arányának növekedése. Az idős cukorbetegek ellátása fokozódó kihívás a háziorvosok, a területtel foglalkozó szakorvosok, szakápolók, dietetikusok és a teljes egészségügyi rendszer számára. A diagnózis gyakran késik, és csak akut anyagcsere-kisiklás, interkurrens betegség, sőt már kialakult szövődmény miatt kerül felismerésre. A klinikai kép heterogén, ennek megfelelően a kezelés is sokszínű, nincsenek minden idős ember- re érvényes sémák. Mindezek tudatában nehezen érthető, milyen kevés időskorra vonatkozó diabetológiai evidenciával rendelkezünk. A 70 év feletti betegek rendszerint nem választhatóak be a klinikofarmakológiai vizsgálatokba, ha mégis, a társbetegségek, az egyidejűleg szedett gyógyszerek kizárási kritériumok lehetnek. Gyakoribbak a vizsgálat során a nemkívánatos események, a betegek kilépése. Akadályozott lehet az együttműködés szellemi, fizikai okokból is. A mérleg másik serpenyőjében a széles merítési lehetőség, nagy gyakorlati 
1. táblázat. Érvek az idős betegek gyógyszervizsgálati részvétele mellett és ellen

\begin{tabular}{|c|c|}
\hline A bevonás mellett & A bevonás ellen \\
\hline Segítséget igénylő populáció & Kizáró társbetegségek \\
\hline Széles merítési lehetőség & Kizáró gyógyszerek \\
\hline Nagy gyakorlati jelentőség & Csökkenő részvételi kedv \\
\hline Határozott biztonsági adatok & Több várható kiesés \\
\hline Több végponti esemény & Több adverz esemény \\
\hline Több idő az együttmüködésre & Csökkenő együttmüködés \\
\hline
\end{tabular}

jelentőség és haszon áll. Az 1. táblázat az időskorban végzett gyógyszervizsgálatok melletti és elleni érveket veszi számba.

\section{Ajánlások és mérlegelési szempontok az antidiabetikus kezelés során}

Az elmúlt években több diabetológiai, geriátriai társaság adott ki szakmai ajánlást az idős cukorbetegek kezeléséről. A Nemzetközi Diabétesz Szövetség (International Diabetes Federation) állásfoglalása nyomán valamennyi funkcionális kategóriákat állapít meg: funkcionálisan független, funkcionálisan függő (esendő és/vagy demens) idős emberekről, valamint életvégi ellátásról beszél. Jó életkilátások, jó biológiai státusz esetén cél a közel normoglykaemia elérése, a fizikailag vagy szellemileg hanyatló betegeknél jellemzően a $8 \%$ alatti $\mathrm{HbA}_{1 \mathrm{c}}$-tartomány, míg az életvégi ellátás keretében a tüneteket okozó hyperglykaemia elkerülése. ${ }^{1}$ A Magyar Diabetes Társaság szakmai irányelve leszögezi: az adott beteg esetében biztonságosan elérhető és fenntartható anyagcserére

2. táblázat. Az ideális - időskori - antidiabetikum jellemzői

- Erőteljes vércukor-, $\mathrm{HbA}_{1 c}$-csökkentés

- Reprodukálható, egyenletes hatás

- Nem okoz hypoglykaemiát

- Testsúlysemleges

- Nem zavarja a gyomor-bélrendszer múködését

- Nem terheli a vesemúködést

- Naponta egyszeri bevétel, fix kombináció

- Gyógyszer-interakció kis veszélye

- Széles körben megfizethető ár kell törekedni. ${ }^{2}$ Kevésbé szigorú céltartományt indokol a hosszabb betegségtartam, rövid életkilátás, szövődmények, súlyos társbetegségek jelenléte, fokozott hypoglykaemia-hajlam.

Ahogy a glikémiás célok kitűzésénél, úgy az antidiabetikum-választásnál is cél a hatékonyság és biztonság egyensúlyának megtalálása. Nem rendelkezünk ideális, minden elvárásunknak megfelelő antidiabetikummal (2. táblázat). Valamennyi gyógyszercsoport esetén találunk előnyös és hátrányos jellemzőket, amelyek az idős páciens adottságaival vethetők össze.

Életkortól függetlenül fontos választási szempont a hatékonyság, az éhomi és étkezés utáni vércukor, a $\mathrm{HbA}_{1 c}$, a glikémiás variabilitás csökkentése. Utóbbi egyenletes hatást, kis napon belüli fluktuációt (enterális és szubkután felszívódást) és nap-nap utáni reprodukálhatóságot is jelent. Kiemelkedő az inzulin-, magas a GLP-1-analóg-, metformin- és szulfanilurea-készítmények hatékonysága. Az egyes csoportokon belül differenciálási szempont a kiszámíthatóbb, egyenletesebb hatásprofil, így a módosított, elnyújtott felszabadulás, pl. metformin, gliclazid, modern bázisinzulinok esetén. Időskorban gyakoribbak, veszélyesebbek a hypoglykaemiás rosszullétek, nehezebb a felismerés és elhárítás. Felértékelődött ezek kockázatának minimalizálása, előrelépést jelentett a DPP-4-gátlók, GLP-1-analógok, SGLT2-gátlók használata, de alacsony a hypoglykaemia rizikója az akarbóz és a pioglitazon esetén is. Az inzulinkészítmények közül a hypoglykaemia veszélyét csökkentik az analóg prandialis és bázis-, valamint analóg mix inzulinok. Időskorban cél lehet a testtömegmegtartás és -csökkentés is. Az elhízott beteg súlyleadása a szénhidrát- és zsíranyagcsere javításán túl csökkenti a vérnyomást, az érrendszeri szövődmények és ízületi betegségek kockázatát, ugyanakkor súlyos interkurrens betegség esetén a túlsúly kedvezőbb kimenetellel társulhat. A testtömegcsökkenés ráadásul 70 év fölött jellemzően izom- és csonttömegveszteséget is jelent. Ha cél a súlyleadás, előnyös a metformin, GLP-1-analóg, SGLT2-gátló terápia, testsúlysemlegesek a DPP4-gátlók, testtömegnövelő a szulfanilurea-, a pioglitazon- és az inzulinkezelés. A metformin, a GLP-1-analóg szerek és az akarbóz alkalmazását gyomor-bélrendszeri mellékhatások gátolhatják, a lassú titrálás és a megfelelő étrendösszetétel azon- 
ban az esetek többségében kiküszöböli ezeket. Romló veseműködés esetén a metformin és az antidiabetikumok többsége fokozatosan leépítendő. E vonatkozásban a legtovább adható a gliquidon, a pioglitazon és a linagliptin, csökkentett dózisban a sitagliptin és a vildagliptin, progrediáló veseelégtelenség esetén azonban előbb-utóbb inzulin bevezetése indokolt. Az idős betegek nagy része árérzékeny. Szerény anyagi lehetőségek a metformin, a szulfanilurea-készítmények és az inzulinkezelés mellett szólnak. A terápiahűséget segítik a fix gyógyszer-kombinációk, kisebb a gyógyszertévesztések esélye is. Mivel a multimorbid beteg rendszerint több gyógyszert szed párhuzamosan, az interakciók esélye fokozott, elsősorban a szulfanilurea-vegyületek esetén. Figyelembe véve a 2-es típusú cukorbetegség progresszív természetét központi jelentőségű a maradék béta-sejt-müködés megóvása. E szempont érvényesítését segíti az inzulinszekréciót nem stimuláló metformin és az SGLT2-gátló szerek, valamint az inkretintengelyen, glukózdependens módon ható készítmények használata. A betegségkarrier előrehaladásával a betegek többsége inzulinkezelésre szorul. Ez esetben az időskorú cukorbetegek többségénél az egyszerűbb BOT (bázisinzulinnal kiegészített orális antidiabetikum terápia) és premix inzulin használat ésszerủ. Az előkevert inzulinanalógok jobb postprandialis vércukorkontrollt biztosítanak. Az aktív, jó biológiai állapotú, együttműködő idős páciens azonban sok esetben az intenzifikált inzulinterápiával nyeri a legtöbbet. Végül, de nem utolsósorban a prandialis (lyspro, aszpart, glulizin) és bázis- (glargin, detemir, degludek) inzulinanalógok kisebb hypoglykaemia-rizikója és rugalmas alkalmazása időskorban is lényeges érv lehet. A detemir inzulinnál a megfigyelések testsúlyelőnyt igazoltak. A második generációs bázisanalógok (glargin $300 \mathrm{E} / \mathrm{ml}$, degludek) tovább csökkentették a hatás variabilitását és a hypoglykaemia esélyét.

\section{3. táblázat. Az orális és injektábilis antidiabetikumok időskori elönyei, hátrányai, speciális jellemzői}

\begin{tabular}{|c|c|c|c|c|}
\hline $\begin{array}{c}\text { Hatóanyag / hatástani } \\
\text { csoport }\end{array}$ & Előnyök & Hátrányok & Speciális megfontolások & Evidenciák \\
\hline Metformin & $\begin{array}{c}\text { magas hatékonyság, } \\
\text { alacsony ár, minimális } \\
\text { hypoglykaemia-kockázat }\end{array}$ & $\begin{array}{l}\text { gastrointestinalis } \\
\text { mellékhatások, } \\
\text { ellenjavallatok }\end{array}$ & $\begin{array}{c}\text { vesefunkció szerinti } \\
\text { alkalmazás }\end{array}$ & kardiovaszkuláris védelem \\
\hline Szulfanilureák & $\begin{array}{l}\text { magas hatékonyság, } \\
\text { alacsony ár }\end{array}$ & $\begin{array}{l}\text { hypoglykaemia, } \\
\text { testsúlygyarapodás }\end{array}$ & $\begin{array}{l}\text { kardiovaszkuláris és } \\
\text { renalis differenciálás }\end{array}$ & \\
\hline DPP-4-gátlók & $\begin{array}{c}\text { alacsony hypoglykaemia- } \\
\text { kockázat, kedvező } \\
\text { mellékhatásprofil }\end{array}$ & viszonylag magas ár & $\begin{array}{l}\text { limitált hosszú távú adat, } \\
\text { pancreashatás }\end{array}$ & \\
\hline GLP-1-analógok & $\begin{array}{c}\text { alacsony hypoglykaemia- } \\
\text { kockázat, } \\
\text { testsúlycsökkentés }\end{array}$ & $\begin{array}{c}\text { gastrointestinalis } \\
\text { mellékhatások, injekció, } \\
\text { magas ár }\end{array}$ & $\begin{array}{l}\text { limitált hosszú távú adat, } \\
\text { pancreashatás }\end{array}$ & $\begin{array}{c}\text { kardiovaszkuláris védelem } \\
\text { (liraglutid) }\end{array}$ \\
\hline SGLT2-gátlók & $\begin{array}{l}\text { alacsony hypoglykaemia- } \\
\text { kockázat, testsúly- és } \\
\text { vérnyomáscsökkentés }\end{array}$ & $\begin{array}{l}\text { genitourinalis infekciók, } \\
\text { folyadékvesztés }\end{array}$ & $\begin{array}{c}\text { vesefunkció-függő hatás, } \\
\text { orthostasis }\end{array}$ & kardiovaszkuláris védelem \\
\hline Akarbóz & $\begin{array}{c}\text { étkezés utáni } \\
\text { vércukorcsökkentés, } \\
\text { minimális } \\
\text { hypoglykaemia-kockázat }\end{array}$ & $\begin{array}{l}\text { gastrointestinalis } \\
\text { mellékhatások, } \\
\text { korlátozott hatékonyság }\end{array}$ & kevés adat & \\
\hline Pioglitazon & $\begin{array}{c}\text { minimális } \\
\text { hypoglykaemia-kockázat }\end{array}$ & $\begin{array}{l}\text { vízretenció, } \\
\text { oedemaképződés, } \\
\text { csonttörések }\end{array}$ & $\begin{array}{c}\text { veseműködéstől } \\
\text { független alkalmazás }\end{array}$ & kardiovaszkuláris védelem \\
\hline Glinidek & prandialis hatás & $\begin{array}{c}\text { korlátozott hatékonyság, } \\
\text { magas ár }\end{array}$ & kevés adat & \\
\hline Inzulinok & $\begin{array}{c}\text { élettani hatás, gyors és } \\
\text { korlátlan hatékonyság, } \\
\text { alacsony költség }\end{array}$ & $\begin{array}{c}\text { hypoglykaemia, } \\
\text { testsúlygyarapodás, } \\
\text { injekció }\end{array}$ & $\begin{array}{l}\text { beteg és ellátó } \\
\text { együttmúködése, } \\
\text { adagbeállítás, } \\
\text { önellenőrzés }\end{array}$ & \\
\hline
\end{tabular}




\section{4. táblázat. Az inzulinkezelési rendszerek időskori előnyei, hátrányai, speciális jellemzői}

\begin{tabular}{|c|c|c|c|}
\hline Inzulinkezelési rendszer & Előnyök & Hátrányok & Speciális megfontolások \\
\hline $\begin{array}{l}\text { BOT (bázis inzulinnal } \\
\text { kiegészített orális terápia }\end{array}$ & egyszerű, biztonságos & $\begin{array}{l}\text { az étkezés utáni emelkedéseket } \\
\text { nem fedi le }\end{array}$ & $\begin{array}{c}\text { külső segítséggel is alkalmazható, } \\
\text { 1., 2. generációs analógok }\end{array}$ \\
\hline Humán premix inzulin & egyszerū, olcsó & $\begin{array}{l}\text { a napi ritmushoz nem } \\
\text { alkalmazkodik, több } \\
\text { hypoglykaemia }\end{array}$ & a leggyakoribb \\
\hline Premix inzulinanalóg & $\begin{array}{c}\text { rugalmas éhgyomri és étkezés } \\
\text { utáni kontroll }\end{array}$ & kissé magasabb ár & $\begin{array}{l}\text { étkezés előtti, utáni adás } \\
\text { lehetősége }\end{array}$ \\
\hline $\begin{array}{l}\text { Humán bázis-bólus } \\
\text { terápia }\end{array}$ & hatékony, olcsó & $\begin{array}{c}\text { több szúrás, mérés, több } \\
\text { hypoglykaemia }\end{array}$ & a teljes napi inzulinigény lefedése \\
\hline $\begin{array}{l}\text { Analóg bázis-bólus } \\
\text { terápia }\end{array}$ & $\begin{array}{c}\text { hatékony, rugalmas, kevesebb } \\
\text { hypoglykaemia }\end{array}$ & több szúrás, mérés & $\begin{array}{c}\text { a leginkább egyénre szabott } \\
\text { kezelés }\end{array}$ \\
\hline
\end{tabular}

A 3. és 4. táblázat az orális és injektábilis antidiabetikumok, inzulinkezelési rezsimek időskori előnyeit, hátrányait foglalja össze.

\section{Adatok a nem inzulintípusú antidiabetikumok időskori alkalmazásával kapcsolatban}

Az elsőként választandó orális antidiabetikum ellenjavallat hiányában időskorban is a metformin. ${ }^{1,2}$ Alkalmazása az elmúlt 20 év során jelentősen változott, a kor mint relatív kontraindikáció említésétől az időskori előnyök előtérbe kerüléséig. Glikémiás hatékonysága mellett alacsony hypoglykaemia-rizikó jellemzi. Étvágy- és testsúlycsökkentő, mérsékli a kardiovaszkuláris szövődmények kockázatát, antithromboticus, antioxidáns, antitumor hatásai ismertek. ${ }^{3,4,5,6}$ Ezen előnyök lényegesen meghaladják a szedése kapcsán felmerülő gastrointestinalis mellékhatások és nagyságrendekkel a $\mathrm{B}_{12}$-vitamin-hiányos anaemia és laktátacidosis kockázatát. Utóbbi megelőzésének elsődleges lépése időskorban az ellenjavallatok (30 alatti GFR, manifeszt hypoxiás állapot) szűrése a bevezetés előtt és a kezelés során rendszeresen. Érdekességként említhető, hogy több megfigyelés szól a metformin öregedési folyamatokat gátló antioxidáns és glikációs végtermék képződés elleni effektusa mellett. ${ }^{7}$

A szulfanilurea-készítmények idős cukorbetegek körében ma is széles körben használatosak. Bár az ajánlásokban háttérbe szorultak, alacsony költségük, markáns vércukorcsökkentő hatásuk és a hármas orális antidiabetikum-kombinációk beteg általi preferálása miatt nem mellőzhetők. Időskori alkalmazásuk elsődleges akadálya a vércukoresés rizikója, amely traumatológiai, szív- és agyi érrendszeri szövődményeket okozhat. ${ }^{8,9,10}$ Kiemelkedik a gyógyszercsoportból a gliclazid, amelynek hypoglykaemia-potenciálja alacsony, kedvezőek pleiotrop, hemoreológiai, antioxidáns, antithrombocyta, endothelre kifejtett hatásai és az a vonása, hogy a myocardium ischaemiás prekondicionálását nem befolyásolja.

A glinidek rövid hatású, prandialis inzulinszekretagógok, étkezéshez kapcsolt bevételük időskorban előnyös lehet, de napi többszöri szedésük és elsősorban áruk miatt széles körben nem terjedtek el.

A DPP4-gátló szerek az elmúlt évek során az antidiabetikus gyógyszerpaletta értékes részévé váltak. A glukózfüggő inzulinszekréciót fokozó és glukagonelválasztást csökkentő hatásuk mellett előnyös testsúlysemlegességük, alacsony hypoglykaemia-veszélyük, a placebóval összevethető mellékhatásprofiljuk. ${ }^{11}$ Költségük közepes, de nem minden időskorú számára vállalható. Több idős betegekre vonatkozó megfigyelést ismerünk a csoport képviselőivel kapcsolatban. ${ }^{12}$ Metforminnal nem megfelelően kontrollált, 65 év feletti cukorbetegek sitagliptinkezelése Avogaro összefoglalása szerint a komparátor antidiabetikumokhoz hasonló hatékonyságú volt, harmadannyi hypoglykaemiával. ${ }^{13}$ Tada és munkatársai retrospektív elemzésében a sitagliptin a palacebóhoz hasonlóan tolerálhatónak bizonyult időskorban. ${ }^{14}$ Barnett megfigyelése szerint a linagliptin második szerként 
placebóval összehasonlítva 70 év feletti cukorbetegeknél $0,64 \% \quad \mathrm{HbA}_{1 \mathrm{c}}$-csökkenést eredményezett, hasonló mellékhatásprofillal. ${ }^{15}$ A vildagliptint vizsgálta Strain munkacsoportja 70 év feletti pácienseknél, átlag $0,9 \% \mathrm{HbA}_{1 c}$-csökkenést találtak, a terápia biztonságos volt. ${ }^{16}$ Öt vizsgálat adatainak elemzése során Karyekar és munkatársai a saxagliptint 65 év feletti betegeknél is hatékonynak és jól tolerálhatónak találták. ${ }^{17}$ Gondolatébresztő Rizzo retrospektív vizsgálata, ahol a DPP4-gátló terápia a szulfanilureakezeléshez képest lassította a kognitív károsodás progresszióját. ${ }^{18}$ A sitagliptinnel végzett, nagy betegszámot felölelő TECOS (Trial Evaluating Cardiovascular Outcomes with Sitagliptin) tanulmány alcsoport-analízise a 75 év feletti betegeknél is igazolta a szer szív-érrendszeri biztonságát. ${ }^{19}$

Az akarbóz vércukorcsökkentő effektusa mérsékelt, elsősorban az étkezés utáni vércukor-emelkedést mérsékli, de időskorban is előnyös, mivel nem hypoglykaemizál. Josse és munkatársainak 12 hónapos vizsgálatában $0,6 \% \mathrm{HbA}_{1 \mathrm{c}}$-csökkenés mellett javította az inzulinszenzitivitást is. ${ }^{20}$

A pioglitazon szintén nem okoz hypoglykaemiát, adása független a vesefunkciótól, kedvezőtlen mellékhatásprofilja (oedemahajlam, csonttörésrizikó) azonban időskori alkalmazását erősen limitálja. Rajagopalan és munkacsoportja vizsgálatukban 65 év feletti betegekben monoterápiában és metformin, szulfanilurea és inzulin mellé adva is hatékonynak találták. ${ }^{21}$

Az SGLT2-gátló szerek a 2-es típusú diabetes mellitus stádiumától függetlenül változatos antidiabetikum és inzulin kombinációk részeként is hatékony vércukorcsökkentők. Előnyös inzulinfüggetlen hatásmechanizmusuk, alacsony hypoglykaemia-potenciáljuk, testsúly- és vérnyomáscsökkentő, valamint a glomerularis hypertensiót mérséklő hatásuk. Időskorban óvatosságra int a folyadékvesztés, az orthostaticus hypotonia, az exsiccosis lehetősége, használatukat azonban elsősorban a genitourinalis fertőzések limitálhatják. Igen ritka mellékhatás a ketoacidosis, amelyre hosszú betegségtartam után jelentkező inzulinhiány, elégtelen veseműködés hajlamosíthatja az idős beteget. Fioretto a dapagliflozinnal kapcsolatos vizsgálatokat tekintette át analízisében. A szer jól tolerálható volt, de a volumenhiány és az átmeneti kreatininemelkedés időskorban gyakoribb volt, mint 65 év alatt, az infekciók előfordulása nem különbözött. ${ }^{22}$

A vércukorcsökkentő kezelést a közelmúltban kardiovaszkuláris végpontú vizsgálatok pozitív eredményei forradalmasították. Az EMPA-REG vizsgálatban az empagliflozin, a LEADER vizsgálatban a liraglutid, míg a SUSTAIN vizsgálatban a semaglutid bizonyult hatékonynak a kardiovaszkuláris morbiditás és mortalitás csökkentésében. Az EMPA-REG tanulmány 2015-ös publikációját követően 2017 júniusában az Amerikai Diabetes Szövetség (ADA) 77. kongresszusán két poszter formájában számoltak be az empagliflozin kedvező időskori hatékonyságáról a szívelégtelenség és a kardiovaszkuláris halálozás megelőzésében. A glikémiás hatékonyság és a hypoglykaemia nem különbözött a 65 év alatti és feletti betegek esetén, az életkor előrehaladásával a folyadékhiány vált gyakoribbá. ${ }^{23,24}$ Mikhail metaanalízisében az SGLT2-gátlók alkalmazása ellen foglal állást esendő és vesebeteg idős páciensek kezelése során. ${ }^{25}$ A LEADER vizsgálat biztonsági analízise során a 65,75 , sőt 85 év feletti betegek eredményeit is elemezték, és a nemkívánatos események gyakorisága az életkor emelkedésével nem növekedett. ${ }^{26}$

A GLP-1-analóg kezelés vércukor-, $\mathrm{HbA}_{1 \mathrm{c}}$-csökkentő effektusa felülmúlja az orális antidiabetikumok hasonló mutatóit. Számos idős beteg esetén akadály a szerek magas árfekvése, sokan nehezen barátkoznak meg a szúrás gondolatával. A liraglutid, dulaglutid, lixisenatid és exenatid vonatkozásában is rendelkezünk idős betegekre vonatkozó adatokkal. Boustani és munkacsoportja a heti egyszeri dulaglutid időskori hatékonyságát és biztonságát a fiatalabb betegekkel egyezőnek találta. ${ }^{27}$ A napi 2-szer adott exenatidot és glargin inzulint hasonlította össze 65 év feletti betegeken végzett tanulmányában Pawaskar. ${ }^{28} \mathrm{Az}$ exenatid vércukorcsökkentő hatékonysága, valamint testsúlycsökkentése nagyobb volt. Raccah összesen hat, lixisenatiddal zajlott III. fázisú vizsgálat eredményeit összesítette, a prandialis GLP-1-analóg 65 és 75 év feletti betegeknél is hatékony és biztonságos volt. ${ }^{29}$ Lingvay és munkatársai a DUAL I és V vizsgálat időskorú alcsoportjának eredményeit ismertették 2016-ban. A liraglutid és degludek inzulin kombinációja szuperiornak bizonyult a $\mathrm{HbA}_{1 \mathrm{c}}$-csökkenés terén az egyes összetevőkhöz és a glargin inzulin feltitrálásához képest, alacsony 
hypoglykaemia-rizikó és testsúlysemlegesség mellett - a 65 év feletti és alatti betegek eredményei egybehangzóak voltak. ${ }^{30} \mathrm{~A}$ fix kombinációt robusztus $\mathrm{HbA}_{1 \mathrm{c}}$-csökkenés jellemzi, előnye az egyszeri szúrás. A mellékhatások (gyomor-bélrendszeri panaszok, hypoglykaemia) ritkábbak, mint amikor a liraglutid vagy a bázisinzulin önállóan kerül beadásra.

\section{Adatok az inzulinkészítmények időskori alkalmazásával kapcsolatban}

Kevés 65 év feletti, még kevesebb 75 év feletti betegekre vonatkozó evidencia áll rendelkezésünkre, ezért ezek különösen értékesek. Nincs bizonyíték, amely idős betegeknél valamely inzulinkezelési rendszer felsőbbrendűségét igazolná.

Lee és munkatársainak öt randomizált, kontrollált tanulmányt felölelő metaanalízise szerint a glargin inzulinnal végzett BOT időskorban is hatékony, kisebb dózis elegendő és kevesebb hypoglykaemia jelentkezik, mint NPH-inzulin mellett. Elsősorban az éjjeli és súlyos hypoglykaemiák száma csökkent, amellett, hogy a 65 év feletti csoportban összességében több vércukoresés fordult elö. ${ }^{31} \mathrm{Ha}-$ sonló összefüggést talált Hermansen és munkacsoportja idősödő és idős, inzulinnaiv betegeknél az orális antidiabetikum mellé adott detemir vonatkozásában. Egyező vércukor- és $\mathrm{HbA}_{1 \mathrm{c}}$-csökkenés mellett kevesebb hypoglykaemia jelentkezett. ${ }^{32}$ Garber vizsgálata szintén a detemir előnyét igazolta az intermedier inzulinhoz képest a hypoglykaemia megelőzésében. ${ }^{33}$ Janka és munkacsoportja közleményében a glargin inzulint a humán premix inzulinnal hasonlította össze metformin- és szulfanilureakombináció kiegészítéseként. A glargin inzulin révén nagyobb volt a vércukorcsökkenés mértéke, több beteg érte el a $7 \%$ alatti $\mathrm{HbA}_{1 c}$-értéket hypoglykaemia nélkül. ${ }^{34} \mathrm{Az}$ új inzulinanalógok egyikét, a degludek inzulint hasonlította össze a glarginnal idős betegcsoportnál Sorli metaanalízise. A degludekkezelésben részesülő betegek 36\%kal kevesebb hypoglykaemiát és $24 \%$-kal kevesebb éjszakai hypoglykaemiát tapasztaltak. ${ }^{35} \mathrm{Az}$ Amerikai Diabetes Társaság 2017-es kongresszusán került ismertetésre a DELIVER 3 vizsgálat, ahol 70 év feletti átlagéletkorú betegeknél a $300 \mathrm{E} / \mathrm{ml}$ glargin inzulin hasonló glikémiás hatékonyság mellett 57\%-kal kevesebb hypoglykaemiát okozott, mint a komparátor bázisinzulinok. ${ }^{36}$ Hasonló következtetésre jutott Yale, aki az EDITION vizsgálatok 65 év feletti alcsoportját elemezte: megegyező $\mathrm{HbA}_{1 \mathrm{c}}{ }^{-}$ csökkenés mellett csökkent az összes és éjszakai hypoglykaemia gyakorisága a $300 \mathrm{E} / \mathrm{ml}$-es glargin révén a $100 \mathrm{E} / \mathrm{ml}$-es glarginhoz viszonyítva. ${ }^{37}$

Jang az aszpart inzulin 30/70-es keverékét több mint 170065 év feletti beteg anyagcsere- és életminőség-javításában találta effektívnek. ${ }^{38}$ Buse és munkatársai a lispro inzulin 25/75 arányú premix készítményét vizsgálták tablettás kezelés mellé adva, amely idős betegeknél hatékonyabb volt, mint a glarginalapú BOT kezelés. ${ }^{39}$ Találunk példát a bázis-bólus és napi kétszeri NPH-kezelés összevetésére is. Hendra és munkatársai 70 év átlagéletkorú betegek féléves kezelése során a lispro étkezési, NPH-bázisinzulin kombináció előnyét bizonyították a kétszeri NPH-inzulin-kezeléshez képest. ${ }^{40}$ Marouf és Sinclair összefoglalójában az aspart inzulin időskori alkalmazásával szerzett tapasztalatokat összesítette. Ezek alapján az aspart hatékony volt a postprandialis vércukor- és $\mathrm{HbA}_{1 \mathrm{c}}$-csökkentés, az éjjeli hypoglykaemia megelőzése és betegelégedettség terén is. ${ }^{41}$ Velussi ápolási otthonban élő idős betegeknél a humán és analóg prandialis inzulint hasonlította össze. Lispro inzulinra váltva az anyagcserekontroll javult, a hypoglykaemiák száma csökkent, a páciensek életminősége jobb lett, visszaváltás után az előnyök eltűntek. ${ }^{42}$ Reza és munkatársai átlag 73 év életkorú, rossz szénhidrátanyagcseréjü betegeknél azt találták, hogy az inzulinbevezetés életminőség-javulást eredményez. ${ }^{43}$ A kisszámú időskori inzulinpumpa-kezelésről szóló adat mind 1-es, mind 2-es típusú cukorbetegségben a fiatalabb korosztályoknál tapasztaltakkal megegyező hatékonyságot mutat. Ennél fontosabb, hogy a szerzők a súlyos hypoglykaemia gyakoriságának csökkenését és a hypoglykaemia-felismerés javulását észlelték. ${ }^{44,45} \mathrm{Az}$ Amerikai Diabetes Társaság ajánlásában megfelelő hatékonyság esetén a pumpakezelés időskori folytatását javasolja.

\section{Konklúzió}

Lassan szaporodnak bizonyítékaink, gyorsan ismereteink az idős cukorbetegek antidiabetikus kezelésével kapcsolatban. A betegcsoport jellem- 


\section{5. táblázat. A sikeres öregedés feltételei}

- Az önállóság megőrzése, az izoláció megszüntetése

- Az aktivitás fenntartása

- Megfelelő mentális és fizikális státusz

- Szociális biztonság

- A krónikus betegségek és geriátriai szindrómák hatékony és

biztonságos kezelése

- A gyógyszer-mellékhatások és -interakciók minimalizálása

- Jó életminőség

zője a multimorbiditás, a geriátriai tünetegyüttesek jelenléte, a jelentős számú gyógyszer egyidejü használata, a változatos klinikai megjelenés. Sérülékeny populáció, ezért a vércukorcsökkentő hatékonyság mellett a mellékhatások, elsősorban a hypoglykaemia elkerülése kiemelten fontos. A cukorbetegség szövődményei gyakoriak, megelőzésük és progressziójuk gátlása ezért szintén lényeges szempont. A szaporodó hatástani csoportok, készítmények farmakodinámiás és farmakokinetikai tulajdonságai, valamint a páciens fizikális, mentális és szociális jellemzői alapján egyre inkább lehetőségünk van egyénre szabott, hatékony és biztonságos terápia kiválasztására. Az egyik leggyakoribb időskori krónikus betegség, a diabetes mellitus eredményes kezelése számos páciens jó életminőségének és sikeres öregedésének fontos záloga (5. táblázat).

Az idős cukorbetegek kezelésével, gondozásával foglalkozó ajánlások köre bővül. Az életmóddal, diétával, vércukor-önellenőrzéssel, orális és injektábilis készítményekkel kapcsolatos evidenciák fokozatosan épülnek be ezekbe az állásfoglalásokba, és a mindennapi tapasztalattal ötvözve lehetővé teszik a geriátriai-diabetológiai ellátás színvonalának emelkedését.

Közlésre érkezett: 2017. július 23.

Közlésre elfogadva: 2017. november 2.

\author{
A szerzö levelezési címe: \\ Dr. Domboróczki Zsolt \\ Szent Lázár Megyei Kórház, Diabetológiai \\ Szakrendelés \\ 3100 Salgótarján, Füleki u. 54-56. \\ E-mail cím:drdzs@freemail.hu
}

Irodalom

1. Colagiuri S (ed.): International Diabetes Federation Global Guideline: Managing older people with type 2 diabetes. IDF, Brusseles, 2013.

2. GaálZ Zs, GeróLL, Hidvégi T, Jermendy Gy, Kempler P, Winkler G, et al.: A diabetes mellitus kórismézésérôl, a cukorbetegek antihyperglykaemiás kezelésérôl és gondozásáról felnôttkorban. A Magyar Diabetes Társaság szakmai irányelve, 2017; Diab Hun 2017; 25: 35.

3. Gregorio F, Manfrini S, Testa I, Filipponi P: Metformin treatment in elderly type 2 diabetic patients: Arch Gerontol Geriatr 1996; 22(Suppl. 1): 261: 70. DOl: 10.1016/0167-4943(96)86947-0

4. Jang K, Chung H, Yoon JS, Moon SJ, Yoon SH, Yu KS, et al.: Pharmacokinetics, safety, and tolerability of metformin in healthy elderly subjects. I Clin Pharmacol 2016; 56(9): 1104-1110. doi:10.1002/jcph.699

5. Libby G, Donnelly LA, Donnan PT, Alessi DR, Morris AD, Evans JM: New users of metformin are at low risk of incident cancer. Diab Care 2009; 32: 1620-1625. doi:10.2337/dc08-2175

6. Papanas N, Maltezos E, Mikhailidis DP: Metformin and cancer: licence to heal? Expert Opin Investig Drugs 2010; 19: 913-917. doi:10.1517/13543784.2010.499122

7. Anisimov VN: Metformin: do we finally have an anti-aging drug? Cell Cycle 2013; 12: 3483-3489. doi:10.4161/cc.26928

8. Bennett WL, Maruthur NM, Singh S, Segal JB, Wilson LM, Chatterjee R, et al.: Comparative effectiveness and safety of medications for type 2 diabetes: an update including new drugs and 2-drug combinations. Ann Intern Med 2011; 154: 602-613. doi:10.7326/0003-4819-154-9-201105030-00336

9. Johnsen SP, Monster TB, Olsen ML, Thisted H, Mclaughlin JK, Sørensen

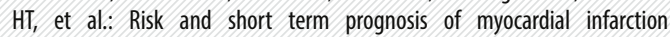
among users of antidiabetic Drugs. Am I Ther 2006; 13 (2): 134-140. doi:10.1097/00045391-200603000-00009

10. Rajpathak SN, Fu C, Brodovicz K, Engel SS, Heaton PC: Sulfonylurea monotherapy and emergency room utilization among elderly patients with type 2 diabetes. Diabetes Res Clin Pract 2015; 109: 507-512. doi:10.1016/j.diabres.2015.05.046

11. Schwartz SL: Treatment of Elderly Patients with Type-2 Diabetes Mellitus: A Systematic Review of the Benefits and Risks of Dipeptidyl Peptidase-4 Inhibitors. Am J Geriatr Pharmacother 2010; 8: 405-418. doi:10.1016/j.amjopharm.2010.10.003

12. Viljoen A, Meek CL, Gadsby R, Viljoen S, Langerman H, Sinclair AJ: The tolerability and safety of DPP-4 inhibitors for the treatment of older people with type 2 diabetes mellitus: an observational study. $\mathrm{Br} J$ Diabetes Vasc Dis 2013; 13: 187. doi:10.1177/1474651413500698

13. Avogaro A, Dardano A, de Kreutzenberg SV, Del Prato S: Dipeptidyl peptidase-4 inhibitors can minimize the hypoglycaemic burden and enhance safety in elderly people with diabetes. Diabetes Obes Metab 2015; 17: 107-115. doi:10.1111/dom. 12319

14. Tada Y, Kanazawa I, Notsu M, Tanaka K, Kiyohara N, Sasaki M, Sugimoto $\mathrm{T}$ : Long-term efficacy and safety of sitagliptin in elderly patients with type 2 diabetes mellitus. Intern Med 2016; 55(10): 1275-1278. doi:10.2169/internalmedicine.55.6011

15. Barnett AH, Huisman H, Jones R, von Eynatten M: Linagliptin for patients aged 70 years or older with type 2 diabetes inadequately controlled with common antidiabetes treatments: a randomised, double blind, placebo-controlled trial. Lancet 2013; 382(9902): 1413-1423. doi:10.1016/50140-6736(13)61500-7

16. Strain WD, Lukashevich V, Kothny W, Hoellinger MJ, Paldanius PM: Individualised treatment targets for eldery patients with type 2 diabetes using vildagliptin as add-on or lone therapy (INTERVAL): a 24 week, randomised, double blind, placebo-controlled trial. Lancet 2013; 382(9890): 409-416. doi:10.1016/50140-6736(13)60995-2 
17. Karyekar CS, Ravichandran S, Allen E, Fleming D, Frederich R: Tolerability and efficacy of glycemic control with saxagliptin in older patients with inadequately controlled type 2 diabetes mellitus.Clin Interv Aging 2013; 8: 419-430. doi:10.2147/CIA.S41246

18. Rizzo MR, Barbieri M, Boccardi V, Angellotti E, Marfella R, Paolisso G: Dipeptidyl peptidase-4 inhibitors have protective effect on cognitive impairment in aged diabetic patients with mild cognitive impairment. J Gerontol A Biol Sci Med Sci 2014; 69(9): 1122-1131. doi:10.1093/gerona/ glu032. Epub 2014 Mar 26.

19. Bethel MA, Engel SS, Green JB, Huang Z, Josse RG, Kaufman KG, et al: Assessing the Safety of Sitagliptin in Older Participants in the Trial Evaluating Cardiovascular Outcomes with Sitagliptin (TECOS). doi:10.2337/dc16-1135

20. Josse RG, Chiasson JL, Ryan EA, Lau DC, Ross SA, Yale JF: Acarbose in the treatment of elderly patients with type 2 diabetes. Diabetes Res Clin Pract 2003; 59(1):37-42. doi:10.1016/50168-8227(02)00176-6

21. Rajagopalan R, Perez A, Ye Z, Khan M, Murray FT: Pyoglitazone is effective therapy for elderly patients with type 2 diabetes mellitus. Drugs Aging 2004; 21(4): 259-271. doi:10.2165/00002512-200421040-00004

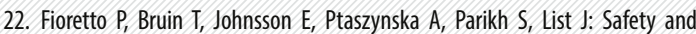
efficacy of the SGLT2 inhibitor dapagliflozin in older patients with type 2 diabetes. Diabetologia 2013; 56: S383.

23. Monteiro P, Schaper N, Hantel S, Woerle HJ, Inzucchi SE, Fitchett D: Effect of empagliflozin on heart failure outcomes in subgroups by age: results from EMPA-REG OUTCOME. Presented as a poster (P129) at the 4th Clinical Congress of American Association of Clinical Endocrinologists: November 3-5, 2016

24. Fitchett D, Ridderstrale M, Toural E, Gillanovic Kis S, Woerle HJ, et al: Effect of Empagliflozin on Cardiovascular Death in Subgroups by Age: Results from EMPA-REG OUTCOME. Presented as a poster (P16) at the 5th Primary Care Cardiovascular Conf' Issues and Answers in Cardiovascular Disease, Nottingham, November 4-5, 2016.

25. Mikhail N: Use of sodium-glucose cotransporter type 2 inhibitors in older adults with type 2 diabetes mellitus. South Med J 2015; 108: 91-96. doi:10.14423/SMJ.0000000000000235

26. Marso SP, Daniels GH, Brown-Frandsen K, Kristensen P, Mann JFE, Nauck M, et al: Liraglutide effect and action in diabetes: evaluation of cardiovascular outcome results (LEADER) trial. N Engl J Med 2016; 375: 311-322. doi:10.1056/NEJMoa1603827

27. Boustani MA, Pittman IV, Yu M, Thieu VT, Varnado 0J, Juneja R: Similar efficacy and safety of once-weekly dulaglutide in patients with type 2 diabetes aged $\geq 65$ and $<65$ years. Diabetes Obes Metab 2016; 18(8): 820-828. doi:10.1111/dom.12687

28. Pawaskar M, Li Q, Reynolds MW: Metabolic outcomes of elderly patient populations initiating exenatide BID vs. insulin glargine in an ambulatory care setting. Curr Med Res Opin 2012; 28: 991-997. doi:10.1185/03007995.2012.686901

29. Raccah D, Miossec P, Esposito V, Niemoeller E, Cho M, Gerich J: Efficacy and safety of lixisenatide in elderly (65 years old) and very elderly (75 years old) patients with type 2 diabetes: an analysis from the GetGoal phase III programme. Diabetes Metab Res Rev 2015; 31: 204-211. doi:10.1002/dmrr.2588

30. Lingvay I, Sorli C, Sutton Linjawi, Abrahamsen TJ, Lehmann L, Liebl A: Safe and effective lowering of blood glucose with insulin degludec/liraglutide (IDeglira) in elderly patients with type 2 diabetes uncontrolled on oral antidiabetic drugs and/or insulin glargine (IGlar). Presented as a poster at the 76th Annual American Diabetes Association (ADA) Scientific Sessions: June 10-14, 2016; New Orleans, LA.
31. Lee P, Chang A, Blaum C, Vlajnic A, Gao L, Halter J: Comparison of safety and efficacy of insulin glargine and neutral protamin hagedorn insulin in older adults with type 2 diabetes mellitus: resultes from a pooled analysis. J Am Geriatr Soc 2012; 60: 51-59. doi:10.1111/j.1532-5415.2011.03773.x

32. Hermansen K, Davies M, Derezinski T, Martinez Ravn G, Clauson P, Home P: A 26-week, randomized, parallel, treat-to-target trial comparing insulin detemir with NPH insulin as add-on therapy to oral glucose-lowering drugs in insulin-naive people with type 2 diabetes. Diab Care 2006; 29: 1269-1274. doi: $10.2337 / \mathrm{d} 005-1365$

33. Garber AJ, Clauson P, Pedersen CB, Kølendorf K: Lower risk of hypoglycemia with insulin detemir than with NPH insulin in older persons with type 2 diabetes: A pooled analysis of phase III trials. J Am Geriatr Soc 2007; 55: 1735-1740. doi:10.1111/j.1532-5415.2007.01414.x

34. Janka HU: Insulin therapy in elderly patients with type 2 diabetes: the role of insulin glargine. Diabetes Obes Metab 2008; 10(Suppl. 2): 35-41. doi:10.1111/j.1463-1326.2008.00843.X

35. Sorli C, Warren M, Oyer D, Mersebach C, Johansen T, Gough SC: Elderly patients with diabetes experiense a lower rate of nocturnal hypoglycemia wit insulin degludec than with insulin glargine: a meta-analysis of phase Illa trials. Drugs Aging 2013; 30: 1009-1018. doi:10.1007/s40266-013-0128-2

36. Zhou FL, Ye F, Gupta V, Gupta R, Sung J, Berhanu P, Blonde L: Older adults with type 2 diabetes experience less hypoglycemia when switching to insulin glargine $300 \mathrm{U} / \mathrm{ml}$ (Gla-300) vs. other basal insulins (DELIVER 3 Study). Presented as a poster at the 77th Annual American Diabetes Association (ADA) Scientific Sessions: June 9-13, 2017; San Diego, CA.

37. Vale JF, Aroda VR, Charbonnel B, Ritzel R, Merino-Trigo A, Stella P, et al: Older people with type 2 diabetes: glycemic control and hypoglycemia risk with new insulin glargine $300 \mathrm{U} / \mathrm{mL}$. Diabetes 2015; 64(Supplement 1): A252-991-P.

38. Jang HC, Lee SR, Vaz JA: Biphasic insulin aspart 30 in the treatment of elderly patients with type 2 diabetes: a subgroup analysis of the PRESENT Korea NovoMix study. Diabetes, Obesity and Metabolism 2008; 11: 20-26. doi:10.1111/j.1463-1326.2008.00891.x

39. Buse JB, Wolffenbuttel BH, Herman WH, Hippler S, Martin SA, Jiang HH, et al.: The DURAbility of Basal vs. Lispro mix 75/25 insulin Efficacy (DURABLE) trial: comparing the durability if lispro mix 75/25 and glargine. Diab Care 2011; 34(2): 249-255. doi:10.2337/dc10-1701

40. Hendra TJ, Taylor CD: Effect of insulin on the quality of life of elderly type 2 diabetic subject - a randomised trial. Age Aging 2001; 30(suppl 2): 70.

41. Marouf $E$, Sinclair AJ: Use of short-acting insulin aspart in managing older people with diabetes. Clin Interv Aging 2009; 4: 187-190.

42. Velussi M: Lispro insulin treatment in comparison with regular human insulin in type 2 diabetic patients living in nursing homes. Diabetes Nutr Metab 2002; 15: 96-100.

43. Reza M, Taylor CD, Towse $K$, Ward JD, Hendra TJ: Insulin improves well-being for selected elderly type 2 diabetic subjects. Diabetes Research and Clinical Practice 2002; 55(3): 201-207. doi:10.1016/50168-8227(01)00327-8

44. Matejko B, Cyganek K, Katra B, Galicka-Latala D, Grzanka M, Malecki MT, et al.: Insulin pump therapy is equally effective and safe in elderly and young diabetes patients. Rev Diabet Stud 2011; 8: 254-258. do: 10.1900/RDS.2011.8.254

45. Herman WH, llag LL, Johnson SL, Martin CL, Sinding J, Al Harthi A, et al.: A clinical trial of continuous subcutaneous insulin infusion vs. multiple daily injections in older adults with type 2 diabetes. Diab Care 2005; 28: 1568-1573. doi:10.2337/diacare.28.7.1568 